\section{The prevalence of Xerostomia after doing radiation therapy in patients with head and neck cancer}

\author{
Barunawaty Yunus*
}

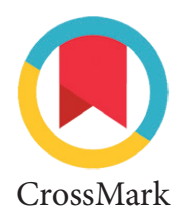

CrossMark
Department of Dental Radiology, Faculty of Dentistry, Hasanuddin University Makassar, Indonesia

*Correspondence to: Barunawaty Yunus, Department of Dental Radiology, Faculty of Dentistry, Hasanuddin University Makassar, Indonesia

barunawaty@yahoo.com

Received 22 August 2016

Revised 30 November 2016

Accepted 03 January 2017

Available online 01 April 2017

Abstract

Objective: To investigate the prevalence of xerostomia after radiation therapy in patients with cancer in head and neck area.

Material and Methods: The subjects of this study were patients with cancer in head and neck area who underwent radiotherapy treatment at Hasanuddin University teaching hospital, subjects were then taken saliva before and after given a total dose of $20 \mathrm{~Gy}$ and a total dose of
$40 \mathrm{~Gy}$. The analysis of the data processed by the computer program and the Wilcoxon test significance level is accepted when $p<0.05$.

Results: The mean bulk saliva before radiotherapy was higher than average of saliva secretion after radiotherapy total dose of $20 \mathrm{~Gy}$ and $40 \mathrm{~Gy}$. Conclusion: A total dose of radiation therapy of $20 \mathrm{~Gy}$ and $40 \mathrm{~Gy}$ may reduce the secretion of saliva in patients with cancer in head and neck area.

Keywords : Radiotherapy, Head and neck cancer, Xerostomia, The bulk of saliva

Cite this Article: Yunus B. 2017. The prevalence of Xerostomia after doing radiation therapy in patients with head and neck cancer. Journal of Dentomaxillofacial Science 2(1): 12-14. D0l: 10.15562/jdmfs.v2i1.459

\section{Introduction}

Development of the use of X-rays increased comprehensively after X-rays discovered by Wilheim Conrad Rontgen in 1895, both in the fields of industry, health sector includes the field of dentistry. In the health field, radiation is used as a diagnostic and therapeutic tool. The use of radiation therapy is called radiotherapy as one of the therapies to treat cancer. ${ }^{1,2}$

Cancer therapy has three basic treatments: surgery, radiotherapy and chemotherapy. Radiotherapy is increasingly being used as primary therapy in the treatment of head and neck cancer. Radiotherapy uses high-energy particles or waves such as gamma rays, electron beams, photons, protons and neutrons to destroy the DNA of cancer cells so it cannot grow and divide again. ${ }^{2,3}$

Radiotherapy also have some effects in the oral cavity. The effects can be acute effects in the oral soft tissue such as mucositis, xerostomia, secondary infections and chronic effects in the hard tissue such as osteoradionecrosis and caries. These complications can be temporary. ${ }^{4}$

Xerostomia is one side effect of radiation therapy which are most common affect the head and neck. This situation is a symptom and not a disease, which is generally associated with reduced saliva. For patients this situation is not pleasant so are the dentists where they consider it as a difficult problem. Therefore, it is important for dentists to be aware of the problem of xerostomia as a side effect of radiation therapy, accordingly appropriate treatment can be done to minimize the side effects of radiation therapy. In patients with carcinoma of the neck and the head, radiation therapy is often done so that the salivary glands are often affected in a radiation field that causes interference with the function of the salivary glands, resulting in xerostomia. ${ }^{5}$

An estimated $30 \%$ of patients aged 65 years above who suffer from this disorder. Xerostomia which is caused by a medication is the most common disorder, because most elderly patients must have experienced of the treatment that uses drugs that can cause salivary hypofunction. The prevalence of xerostomia increased to $60 \%$ in patients living with long-term treatment, such as in patients using psychiatric drugs, anti-hypertensive or renal disease. ${ }^{5}$

Seeing this report, the researchers wanted to see the prevalence of xerostomia in patients with head and neck cancer who got radiation treatment.

\section{Material and Methods}

This study included within the scope of Dental and Oral Pathology as well as Radiation Oncology. The study took a place at Dental Hospital, Department of Radiotherapy, Hasanuddin University from June to September 2015. Based on the objectives to be achieved, then the type of research used in this study was a quasi-experimental design with pre-test and post-test design. The subjects of this study were patients with head and neck cancer area undergoing radiotherapy treatment in the area of head and neck radiotherapy Installation at Hasanuddin University from June to September 2015.

Subjects were selected with consecutive sampling method. Materials used in this study were saliva, gauze and alcohol $70 \%$ and some tools 
Table 1 Distribution of the sample according to age group

\begin{tabular}{lcc}
\hline Age (year) & Amount & $\%$ \\
\hline $21-40$ & 4 & 40 \\
$41-60$ & 3 & 30 \\
$61-80$ & 3 & 30 \\
Total & 10 & 100
\end{tabular}

Table 2 Distribution of the sample by gender

\begin{tabular}{lcc}
\hline Sex & Amount & $\%$ \\
\hline Male & 8 & 80 \\
Female & 2 & 20 \\
Total & 10 & 100
\end{tabular}

Table 3 Results of saliva bulk ratings

\begin{tabular}{lcc}
\hline Curah Saliva & Mean $(\mathbf{m l})$ & $\begin{array}{c}\text { Std. Deviation } \\
(\mathbf{m l})\end{array}$ \\
\hline Bulk of saliva before radiotherapy & 1.96 & 0.09 \\
Bulk of saliva after radiotherapy total dose 20 Gy & 0.97 & 0.06 \\
Bulk of saliva after radiotherapy total dose 40 Gy & 0.53 & 0.08 \\
\hline
\end{tabular}

\begin{tabular}{lc}
\hline Table 4 Results of test calculations normality of data \\
\hline Bulk of Saliva & P \\
\hline Bulk of Saliva 1 & $0.245^{\star}$ \\
Bulk of Saliva 2 & 0.015 \\
Bulk of Saliva 3 & 0.045 \\
\hline
\end{tabular}

*) Normal distribution of data, $\mathrm{p}>0.05$

$\mathrm{p}<0.05$ can be concluded that the data distribution is not normal.

Table 5 The result of the calculation of non-parametric statistical analysis of friedman test

\begin{tabular}{ll}
\hline Bulk of Saliva & $\mathbf{P}$ \\
\hline Bulk of Saliva 1 & $3.00^{\star}$ \\
Bulk of Saliva 2 & $2.00^{\star}$ \\
Bulk of Saliva 3 & $1.00^{\star}$ \\
\hline
\end{tabular}

*) Normal distribution of data, $\mathrm{p}>0.05$

Table 6 Saliva secretion in three different condition

\begin{tabular}{lccc}
\hline Saliva collected & I & II & III \\
\hline Saliva secretion & $0.005^{\star}$ & $0.004^{\star}$ & $0.005^{\star}$ \\
\hline
\end{tabular}

${ }^{*} \mathrm{p}<0.005$; Wilcoxon rank-sum text

in the form of saliva container, rod stirrer and a measuring cup. Before the study, researchers asked permission to conduct research to patients who met the inclusion criteria then explained that they would be included in this study and asked their willingness to participate in the study.
Patients were given the explanation that the saliva output would be measured. Then intervention in accordance with the flow of research was done. Subject bows her head in deep and perform one movement to eliminate the swallowing of saliva collected before the time of calculation. Subject let the saliva in his mouth flow through the lower lip into the measuring tube and the end time of the collection of the subject spit out the rest of the saliva did not flow into the tube. Those processes were done 3 times with different doses for either before and after radiotherapy. Before radiotherapy the total dose was $20 \mathrm{~Gy}$ and after radiotherapy the total dose taken was $40 \mathrm{~Gy}$.

\section{Results}

This study was conducted for four months to the patients who were already registered to undergo radiotherapy treatment of head and neck area in the Dental Hospital, Department of Radiotherapy, Hasanuddin University. Samples were taken by consecutive sampling where all patients who met the inclusion criteria included in the study until the required sample size was met till finally 10 samples were obtained in the study.

The youngest age in the study was 30 years old, while the oldest was 63 years of age. Of the 10 samples of the study, the largest age group was 21-40 years old consisted of 4 samples.

In this study, the number of samples with the male sex more than women samples.

Table 3 shows that the average rainfall saliva before radiotherapy was higher than average rainfall saliva after radiotherapy total dose of 20 Gy and 40 Gy. It also explains that the more the total dose of radiotherapy, the rainfall will decrease saliva.

Test of distribution normality of data was conducted to determine the condition of the distribution of research data. Since there were not normally distributed data, then a statistical analysis of non-parametric friedman test was used.

Seeing the value of $\mathrm{p}>0.05$ in all three groups, it can be concluded that the data were normally distributed.

Wilcoxon test resulted in the significant value of 0.005 in bulk saliva I, the bulk saliva 2 of 0.004 and the bulk of salivary 3 significance value of 0.005 . From these results, the significant value of the three groups of saliva bulk of $p<0.05$, it can be concluded that there is a significant difference between the bulk saliva before radiotherapy, salivary output after a dose of $20 \mathrm{~Gy}$ and $40 \mathrm{~Gy}$ dose of bulk saliva after theraphy, further there was a decrease in rainfall of saliva in patients undergoing radiotherapy of the head and neck area. 


\section{Discussion}

This study was conducted to 10 patients undergoing radiotherapy treatment in head and neck area at Dental Hospital, Department of Radiotherapy, Hasanuddin University from June to September 2015. The collection of saliva from 10 samples before radiotherapy results obtained minimum and maximum yield $2.1 \mathrm{ml} 1.8 \mathrm{ml}$ after radiotherapy dose a total of 20 Gy the results obtained minimum and maximum yield $1.1 \mathrm{ml}, 0.9$ $\mathrm{ml}$, after a total dose of 40 Gy radiotherapy results obtained minimum and maximum yield $0.7 \mathrm{ml}, 0.4$ $\mathrm{ml}$. The results of data analysis showed the average rainfall saliva before patients undergo radiotherapy treatment was $1.96 \pm 0.09$, the average rainfall saliva after a total dose of 20 Gy radiotherapy was $0.97 \pm$ 0.06 and the mean bulk saliva after a total dose of 40 Gy radiotherapy is $0.53 \pm 0.08$.

According to research conducted by Agustin ${ }^{6}$ that the results of research conducted on 10 patients consisted of 5 women and 5 men in Yogyakarta at RS.DR.Sardjito, Radiology Unit shows that there are differences in salivary output in patients radiotherapy head area and neck either before or after radiotherapy. ${ }^{6}$ Study to 10 patients in the radiotherapy unit RS. Dr. Kariadi, Semarang showed that there is a significant decrease in salivary output in patients with head and neck radiotherapy area.?

Decrease in rainfall of saliva in this study because the area of head and neck radiotherapy involving the salivary glands in the area of radiation that can cause damage to cells of the salivary gland secretion. ${ }^{8}$ salivary $\mathrm{pH}$ will decrease as salivary flow also decreased.

In the next phase, the characteristics of the salivary glands was replaced by remnants of the duct and connective tissue filled with lymphocytes and plasma cells. Progressive glandular atrophy, fibrosis and reduced expenditure saliva begins immediately after the initial radiation exposure and intensive exposure afterward. ${ }^{10}$

Although the salivary glands do mitotic slowly, salivary gland is a gland that radiosensitive. Acini of salivary gland is the most radiosensitive where the parotid gland serous acini more radiosensitive than acini mukous submandibular and sublingual glands. ${ }^{10}$

Patients who received radiotherapy treatment of head and neck area experienced a significant increase in the form of saliva concentrations of sodium, chlorine, calcium, magnesium and protein accompanied by a decrease in spending (flow rate) and decreased in salivary bicarbonate concentrations. Salivary bicarbonate buffer system is very important to against acid formation by dental plaque, but only in high concentrations. Increased bicarbonate concentration resulted in an increase in the $\mathrm{pH}$ of saliva.
As a result of the reduced concentration of bicarbonate, xerostomia sufferers will have a low salivary $\mathrm{pH}$ and low capacity screening. These changes make saliva contains a higher salt and expenditure salivary secretion is also worse in patients with xerostomia compared with saliva in normal people. ${ }^{10}$

\section{Conclusion}

Radiotherapy of the head and neck area total dose $20 \mathrm{~Gy}$ and $40 \mathrm{~Gy}$ may affect rainfall saliva. There are differences between the bulk saliva before radiotherapy with bulk saliva after radiotherapy total dose of $20 \mathrm{~Gy}$, bulk saliva before radiotherapy with bulk saliva after radiotherapy total dose of $40 \mathrm{~Gy}$ and the bulk of saliva after radiotherapy total dose of $20 \mathrm{~Gy}$ to bulk saliva after radiotherapy total dose of 40 Gy. People who undergo radiation therapy, especially cancer of head and neck area prone to symptoms of xerostomia due to reduced secretion of saliva during the therapy process.

\section{Conflict of Interest}

The authors report no conflict of interest.

\section{References}

1. Rasad S. Radiologi diagnostik. 2nd ed. Jakarta: Balai Penerbit FKUI; 2010. p. 1- 26.

2. Burket LW, Greenberg MS, Glick M, et al. Oral cancer. In: Epstein J, Wall IVD. Editors. Burket's oral medicine: diagnosis and treatment. 10th ed. Philadhelpia: J.B.Lippincott Co; 2008. p. 194-226.

3. Susworo R. Radioterapi : dasar-dasar radioterapi dan tata laksana radioterapi penyakit kanker. Jakarta: Penerbit Universitas Indonesia; 2007. p. 1-78.

4. Moller PPM, Ozsahin M, Monnier P. A prospective study of salivary gland function in patient undergoing radiotherapy for squamous cell Carcinoma of the Oropharynx. 2004 [cited 2011 Dec 11]; Available from: http://www.ncbi.nlm. nih.gov/pubmed/14970776.

5. Rini E. Xerostomia sebagai salah satu efek samping terapi radiasi. USU e-Repository 2005.

6. Agustin RN. Pengaruh radioterapi area kepala dan leher terhadap perbedaan Curah Saliva pria dan wanita. Yogyakarta: Fakultas Kedokteran Gigi Universitas Gadjah Mada; 2006.

7. Fithrony M. Pengaruh radioterapi area kepala dan leher terhadap Curah Saliva. Semarang: Universitas Diponegoro; 2012.

8. Meidyawati R. Pengaruh radiasi dosis terapi terhadap kekerasan email yang dilapisi Varnish Fluor. Jakarta; Indonesia University; 2003.

9. Amerongen AVN. Ludah dan kelenjar ludah: arti bagi kesehatan gigi. Yogyakarta: Gadjah Mada University Pers. p. 1-39.

10. Andrews N, Griffiths C. Dental Complications of Head and Neck Radiotherapy: Part 1. Aust Dent J. 2001;46: 88-94.

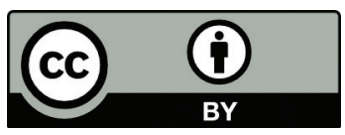

This work is licensed under a Creative Commons Attribution 